\title{
INFLUENCE OF ETHANOLIC EXTRACT OF ASPILIA AFRICANA LEAF ON THE PERFORMANCE AND EGG QUALITIES OF JAPANESE QUAILS
}

\author{
OKO, O. O.K. OZUNG, P. O. AND ABANG, F. B. \\ (Received 28 September 2018; Revision Accepted 12 November 2018)
}

\begin{abstract}
A 16-week trial evaluated the effects of ethanolic extract of Aspiliaafricana leaf (EeAaL) on the growth performance, carcass and egg characteristics of growing and laying quails. One hundred and eighty (180), one-week old Japanese quail chicks were assigned to six experimental diets $(0,2.5,5,7.5,10 \%$ EeAaL or $0.02 \%$ oxytetracycline). Each treatment had 30 birdswhich were further subdivided into three replicates of 10 birds. Each replicate was housed in a pen under the deep litter system; feed and water were provided ad libitum.Growth performance and egg characteristics(egg quantity and quality) indices were subjected to the one-way ANOVA in a completely randomized design (CRD). No significant $(P>0.05)$ effect of EeAaL was observed between treatments on the final body weight and daily weight gains of quails. Feed conversion ratio $(4.95-5.28)$ was significantly $(P<0.05)$ improved in quails fed $2.5-$ 7.5\% EeAaL diets. Zero mortality was observed in quails fed $5-10 \%$ EeAaL diets compared to other treatments. EeAaL supplementation reduced $(P<0.05)$ the amount of fat deposition in quail carcass, thus improving the carcass quality. The efficacy ofEeAaL was more pronounced in laying than growing quails where significant $(P<0.05)$ differences were observed on some external and internal egg characteristics, whereas egg composition did not differ $(P>0.05)$ between treatments. Egg number, hen day production, albumen weight,yolk weight, shell thickness and yolk colour were significantly improved following dietary EeAaL supplementation,indicative of strong growth promoting and stimulatory effects. Therefore, for improved carcass and egg performances up to $7.5 \%$ EeAaL shoud be supplemented intoquail diets.
\end{abstract}

KEYWORDS: Leaf extract, growth rate, egg characteristics, bush marigold, quails

\section{INTRODUCTION}

Dietary manipulations involving nutritional, sensory, chemical, physical and physiological characteristics of feed materials are of the innovative strategies developed for improving the quality of animal products (RunjaicAntic et al., 2010; Agiang et al., 2011). In the developing countries such as Nigeria, animal protein shortage with its increasing demand has remain a major challenge for the Livestock sector and several research efforts are geared towards ameliorating this situation. Diversification of the livestock industry and exploitation of locally, available cheap feed resources are the current research focus (Oko et al., 2011; Abang et al., 2017; Malik et al., 2018).

The Japanese quail (Coturnix coturnix japonica) popularly known as the "quintessential micro-livestock" is one of the animal species that is gaining attention in food security programmes (FAO, 2012) due to its suitability in producing meat and eggs at the shortest time (Oko et al., 2012; Egbeyale et al., 2013; Akintunde et al., 2017).Quail breeding is also known as coturniculture (Mondry, 2016). Lee et al.(2005) further noted that quail meat and eggs are of public health significance because of their high protein value and low caloric contents thus, the ideal food for people with several health issues.

The suitability of a number of unconventional feed ingredients including Aspilia africana leaf (Oko et al., 2011, 2012, 2013), kenaf seed (Odetola et al., 2017), mango seed (Abang et al., 2017), pigeon pea seed (Akintunde et al., 2017), cassava peel meal (Malik et al., 2018) and sweet potato peels (Edache et al.,2018) in improving quail productivity are currently being explored. Aspilia africana (Bush marigold) an obnoxious plant is successfully being incorporated into animal diets (Etim et al.,2017) including poultry (Agiang et al., 2011; Oko et al., 2011) due to its numerous nutritional properties. Its leaf meal and aqueous extract showed significant effects as protein source and growth promoter, respectively in poultry(Agiang et al., 2011; Oko et al., 2011). Egg qualities including yolk colour improved significantly following Aspilia africana supplementations.

Thus, this present study further evaluated the effects of

Oko, O. O.K. Department of Animal Science, University of Calabar, PMB 1115, Calabar, Nigeria

Ozung, P. O. Department of Animal Science, University of Calabar, PMB 1115, Calabar, Nigeria

Abang, F. B. Department of Animal Production, Federal University of Agriculture, Makurdi, Nigeria 
various levels of ethanolic extract of Aspilia africana leaf on the performance and egg characteristics of laying Japanese quails.

\section{Materials and Methods}

The research was conducted at the Poultry unit of the University of Calabar, Teaching and Research farm, Calabar, Nigeria. The site is located in the rain forest zone of South-south Nigeria on Latitude $4{ }^{0} 57^{1} \mathrm{~N}$ and Longitude $8^{0} 19^{1} \mathrm{E}$ and $42 \mathrm{~m}$ above sea level. The area is of humid climate with a mean annual rainfall of $1,830 \mathrm{~mm}$ and temperature of $25^{\circ}-31^{\circ} \mathrm{C}$ (Google Earth,2016).

\section{Test ingredient}

Aspilia africana plants used in this study were harvested within the vicinity of the University of Calabar, Teaching and Research farm. The plant was obtained by harvesting whole field plant above $3 \mathrm{~cm}$ stubble height within the mid vegetative to flowering stage of development as previously described (Oko et al., 2010). The leaves were sorted, air dried for $72 \mathrm{hrs}$. and the dried leaves were ground using a hammer mill fitted with $1 \mathrm{~mm}$ screen into Aspilia africana leaf meal. Exactly $200 \mathrm{~g}$ of leaf meal was measured into a conical flask and soaked in $600 \mathrm{ml}$ of $80 \%$ ethanol for $24 \mathrm{hrs}$.at room temperature. The slurry was filtered (using Whatman filter paper No.4) into a $250 \mathrm{ml}$ conical flask. The filtrate was then lyophilized to produce gel-like ethanolic extract of Aspilia africana leaf (EeAaL). Extract was prepared frequently as required.

\section{Experimental diets}

Basal (antibiotic-free) diets were formulated to meet the nutrient requirements of growing and laying quails (Table 1).

Table 1: Composition of basal diets

\begin{tabular}{|c|c|c|}
\hline Ingredients & Growing Period & Laying Period \\
\hline Maize & 41.57 & 37.80 \\
\hline Soyabean meal & 35.43 & 41.70 \\
\hline Crayfish dust & 5.00 & 5.00 \\
\hline Wheat offal & 10.00 & 4.00 \\
\hline Palm kernel cake & 4.00 & 2.00 \\
\hline Dicalcium phosphate & 2.50 & 4.00 \\
\hline Limestone & 0.00 & 4.00 \\
\hline *Vitamin premix & 0.50 & 0.50 \\
\hline Salt & 0.50 & 0.50 \\
\hline Lysine & 0.30 & 0.30 \\
\hline Methionine & 0.20 & 0.20 \\
\hline $\begin{array}{l}\text { Total } \\
\text { Salcis }\end{array}$ & 100 & 100 \\
\hline $\begin{array}{l}\text { Calculated Analysis } \\
\text { Crude protein (\%) }\end{array}$ & 24.00 & 24.00 \\
\hline Calcium (\%) & 0.80 & 3.00 \\
\hline $\begin{array}{l}\text { Metabolisable } \\
\text { (Kcal/kg) }\end{array}$ & $2,750.00$ & $2,650.00$ \\
\hline
\end{tabular}

*Vitamin BCP (premix; 0.25\% vitamins and Trace elements)

To determine the optimum level of ethanolic extract supplementation with the best growth promoting effects, two control diets; negative control (diet 1 - basal diet ) and positive control (diet 2 - basal $+0.02 \mathrm{~g} / \mathrm{kg}$ oxytetracycline) were formulated according to the methods of Denli et al. (2004), and estimated equivalent of $2.5,5,7.5$ and $10 \%$ of ethanolic extract of Aspilia africana leaf (EeAaL) were supplemented into the basal diets to represent diets $3,4,5$ and 6 , respectively. Therefore, a total of six dietary treatments were studied.

\section{Management of experimental birds}

A total of 180 , one-week old quail chicks were assigned to the six experimental diets in a completely randonmized design (CRD). Thirty (30) chicks were alloted to each treatment which was further divided into three replicates of 10 birds each. Each replicate was housed in a pen, feed and water were provided ad libitum. The birds were managed under the deep litter system, according to the Federation of Animal Science Societies' Principles of Animal Care in experimentation set throughout the 16 weeks duration.

\section{Data collection and analysis}

For growing quails, their growth rate (body weight, weight gain, feed intake, feed conversion ratio and mortality) was monitored weekly from weeks $1-6$ of experiment while their carcass quality in terms of dressed, organ and intestinal weights were evalauted at the sixth week.In the laying phase, layers were separated from the malesbased on their body/phenotypic characteristics.According to Mondry(2016)the female Japanese quail is slightly larger than the male and has a lighter throat with black speckles while the male has a darker, caramel - brown throat.Quail eggs from layers were collected (weeks 7 16) twice daily (9.00 and $16.00 \mathrm{~h})$ and feed intake, egg weight, egg size and egg quality were measured weekly. Total amout of eggs laid throughout the period were recorded and hen day production was calculated. On a weekly basis, three freshly laid eggs were randomly picked from each replicate and were used for egg quality determination throughout the ten weeks of collection. Egg weights were measured thereafter, broken individually into a flat plate to assess the internal and external egg quality characteristics. Each shell was 
washed with distilled water in order to eliminate adhering albumen particles, the shell was then air-dried for 24 hours and weighed.

Egg weights were measured using a digital elctronic scale $(G \& G)$. The proportion of albumen, yolk and shell were determined as \% of egg weight. The venier caliper (RS 548-718, Mitutoyo Corporations, Japan) was used in measuring the length, diameter, height of the albumen, yolk and egg. Egg shell thickness including shell membrane was measured at three points; on the end, equatorial region and at the pointed end using a Micrometer Screw Guage (PM 025, Draper Tools Ltd., Eastleigh, UK). These measurements were recorded as mean of pooled values. The number of eggs cracked per treatment were recorded. Egg shape index was calculated as the egg diameter divided by the egg length multiplied by 100 . Yolk visual colour score was determined by matching the yolk with one of the 15 bands of Roche yolk colour fan.
Data collected were subjected to the one-way analysis of variance in a completetely randomized design using the generalized linear model and significant means were seperated using the Tukey's methods of the GENSTAT (2011) software package.

\section{Results and Discussion}

Each $2.5 \mathrm{~kg}$ contained;

Vitamin A 10,000,000 I.U, Vitamin D 2,000,000 I.U, Vitamin E 20,000I.U, Vitamin K 2,250mgr, Thiamine $1,750 \mathrm{mgr}$, Riboflavin $\mathrm{B}_{2}$ 5,000mgr, Pyridoxine $\mathrm{B}_{6} 2,750 \mathrm{mgr}$, Niacin $27,500 \mathrm{mgr}$, Vitamin $\mathrm{B}_{12} 15 \mathrm{mgr}$, Pantothenic acid 7,500 mgr, Biotin 50 mgr, Cholin chloride 400gr, Antioxidant $125 \mathrm{gr}$, Manganese $80 \mathrm{gr}$, Zinc $50 \mathrm{gr}$, Iron $20 \mathrm{gr}$, Copper $5 \mathrm{gr}$, lodine $1.20 \mathrm{gr}$, Selenium $200 \mathrm{gr}$, Cobalt $200 \mathrm{gr}$

\begin{tabular}{|c|c|}
\hline Diet & $\begin{array}{l}\text { Level } \\
\text { supplementation }\end{array}$ \\
\hline 1 & Negative Control \\
\hline 2 & Positive Control \\
\hline 3 & 2.5\% EeAaL \\
\hline 4 & $5.0 \%$ EeAaL \\
\hline 5 & 7.5\% EeAaL \\
\hline 6 & $10.0 \% \mathrm{EeAaL}$ \\
\hline
\end{tabular}

\author{
of Statement \\ Basal diet \\ Basal diet $+0.02 \mathrm{~g} / \mathrm{kg}$ oxytetracycline \\ Basal diet $+4.25 \mathrm{~g} / \mathrm{kg}$ EeAaL \\ Basal diet $+8.49 \mathrm{~g} / \mathrm{kg} \mathrm{EeAaL}$ \\ Basal diet $+12.74 \mathrm{~g} / \mathrm{kg} \mathrm{EeAaL}$ \\ Basal diet + $16.98 \mathrm{~g} / \mathrm{kg} \mathrm{EeAaL}$
}

Table 2. Performance of quails on EeAaL diets

\begin{tabular}{|c|c|c|c|c|c|c|c|c|}
\hline Parameter & NC & PC & $\begin{array}{l}2.5 \% \\
\text { EeAaL }\end{array}$ & $\begin{array}{l}5.0 \% \\
\text { EeAaL }\end{array}$ & $\begin{array}{l}7.5 \% \\
\text { EeAaL }\end{array}$ & $\begin{array}{l}10.0 \% \\
\text { EeAaL }\end{array}$ & sem & LSD \\
\hline Initial weight, $\mathrm{g}$ & 16.52 & 16.48 & 16.54 & 16.46 & 16.50 & 16.53 & 0.01 & \\
\hline Final weight, $\mathrm{g}$ & 129.74 & 130.00 & 132.88 & 133.22 & 130.74 & 129.93 & 0.56 & 6.78 \\
\hline Daily, feed intake g/d & $15.70^{\mathrm{a}}$ & $15.03^{b}$ & $13.76^{c}$ & $13.77^{c}$ & $13.77^{c}$ & $13.84^{c}$ & $0.16^{*}$ & 0.44 \\
\hline Daily weight gain, $\mathrm{g} / \mathrm{d}$ & 2.70 & 2.70 & 2.77 & 2.78 & 2.72 & 2.70 & 0.91 & 1.81 \\
\hline $\begin{array}{l}\text { Feed conversionn } \\
\text { ratio }\end{array}$ & $5.82^{\mathrm{a}}$ & $5.57^{\mathrm{b}}$ & $4.97^{\mathrm{d}}$ & $4.95^{\mathrm{d}}$ & $5.06^{\mathrm{cd}}$ & $5.13^{c}$ & $0.02^{*}$ & 0.14 \\
\hline Mortality, \% & $4.00^{a}$ & $2.67^{\mathrm{b}}$ & $1.33^{\mathrm{c}}$ & $0.00^{d}$ & $0.00^{d}$ & $0.00^{d}$ & $0.14^{*}$ & 0.21 \\
\hline $\begin{array}{l}\text { Carcass yield, \%LW } \\
\text { Organ Weight, \%LW: }\end{array}$ & $58.90^{a b}$ & $59.32^{\mathrm{ab}}$ & $59.42^{a}$ & $55.29^{c}$ & $58.22^{b}$ & $54.70^{c}$ & $0.56^{*}$ & 1.13 \\
\hline Gizzard & $3.19^{a}$ & $2.75^{\mathrm{b}}$ & $2.24^{\mathrm{C}}$ & $2.61^{\mathrm{b}}$ & $2.36^{\mathrm{C}}$ & $2.39^{c}$ & $0.08^{*}$ & 0.23 \\
\hline Heart & $0.86^{a b}$ & $0.81^{b}$ & $0.90^{\mathrm{a}}$ & $0.65^{c}$ & $0.43^{d}$ & $0.76^{\mathrm{b}}$ & $0.03^{*}$ & 0.07 \\
\hline Liver & $2.36^{c}$ & $2.49^{c}$ & $2.79^{b}$ & $2.45^{\mathrm{C}}$ & $2.02^{d}$ & $3.09^{a}$ & $0.10^{*}$ & 0.26 \\
\hline Abdominal fat & $0.34^{\mathrm{b}}$ & $0.67^{\mathrm{a}}$ & $0.31^{\mathrm{b}}$ & $0.32^{b}$ & $0.24^{c}$ & $0.21^{\mathrm{c}}$ & $0.06^{*}$ & 0.08 \\
\hline Intestine & $5.69^{a}$ & $4.90^{b}$ & $5.77^{a}$ & $4.66^{b}$ & $3.31^{\mathrm{c}}$ & $4.90^{b}$ & $0.28^{*}$ & 0.45 \\
\hline
\end{tabular}

Table 2 presents the impact of dietary ethanolic extract of Aspilia africana leaf (EeAaL) supplementation on the growth performance of growing quails. No significant $(P>0.05)$ effect of EeAaL was observed between treatments on the final body weight and daily weight gains of quails. Whereas, daily feed intake, feed conversion ratio and mortality rate were significantly $(P<0.05)$ different between dietary treatments. Daily feed intake $(13.76-15.70 \mathrm{~g} / \mathrm{d})$ was highest in quails fed the control diet without antibiotics or EeAaL supplements, while quails on EeAaL diets had lower feed intake. Feed conversion ratio (4.95 - 5.28) was significantly $(P<0.05)$ improved in quails fed $2.5-7.5 \%$
EeAaL followed by those on $10 \%$ EeAaL, $0.02 \mathrm{~g} / \mathrm{kg}$ oxytetracycline with the least in quails fed the control diet.

This result indicated that EeAaL supplementation could stimulate digestion process thus improving feed conversion ratio. The inclusion of $5-10 \%$ EeAaL in quail diets led to a zero mortality compared to other dietary treatments suggesting that EeAaL exerted some antibiotic effects in the animals, thus its ability to improve the immunity and disease resistance status of the quails. Results of this present study are consistent with previous studies (Alicicek et al., 2004; Agiang et al., 2011) that plant extracts improved the growth 
performance of growing quails. This report showed that up to $7.5 \%$ EeAaL in quail diets exerted strong antibiotic and growth promoting effects on quails.

Table 2 showed that carcass characteristics of quails fed varying levels of ethanolic extracts of Aspilia africana leaf did not differ $(P>0.05)$ between treatments. Carcass yield of 54.70 - $59.42 \%$ was obtained with quails on $2.5 \%$ EeAaL recording the highest value while the least value was obtained in quails fed $10 \%$ EeAaL. Apart from abdominal fat pad, no significant $(P>0.05)$ effects of dietary treatments were observed on the relative organ weight of quails. At increasing levels of EeAaL supplementation, abdominal fat pad reduced significantly $(P<0.05)$, suggesting that EeAaL could reduce the amount of fat deposition in quail carcass, thus improving the carcass quality. This observation is in line with reports on the use of plant products in poultry diets (Alicicek et al., 2004; Agiang et al., 2011; Oko et al., 2012). Higher carcass yield of $76.11-90.55 \%$ was reported by Malik et al. (2018) in quails fed fermented cassava peels.

The influence of dietary ethanolic extract of Aspilia africana leaf (EeAaL) supplementation on the egg characteristics of Japanese quails are presented in Table 3.

Table 3. Effects of EeAaL diets on the egg quality traits of Japanese quails

\begin{tabular}{|c|c|c|c|c|c|c|c|c|}
\hline Parameter & $\mathrm{NC}$ & $P C$ & $\begin{array}{l}2.5 \% \\
\text { EeAaL }\end{array}$ & $\begin{array}{l}5.0 \% \\
\text { EeAaL }\end{array}$ & $\begin{array}{l}7.5 \% \\
\text { EeAaL }\end{array}$ & $\begin{array}{l}10.0 \% \\
\text { EeAaL }\end{array}$ & sem & LSD \\
\hline \multicolumn{9}{|l|}{ External qualities: } \\
\hline Egg size, $\mathrm{g}$ & $9.99^{b}$ & $9.72^{c}$ & $10.37^{\mathrm{a}}$ & $9.86^{c}$ & $9.41^{d}$ & $10.13^{\mathrm{b}}$ & $0.08^{*}$ & 0.23 \\
\hline Egg width, $\mathrm{mm}$ & $24.08^{a}$ & $23.27^{\mathrm{b}}$ & $23.85^{\mathrm{ab}}$ & $24.11^{a}$ & $22.57^{\mathrm{c}}$ & $23.61^{\mathrm{b}}$ & $0.16^{*}$ & 0.45 \\
\hline Egg length, $\mathrm{mm}$ & $30.95^{\mathrm{a}}$ & $30.30^{\mathrm{ab}}$ & $30.87^{\mathrm{a}}$ & $31.32^{\mathrm{a}}$ & $29.11^{\mathrm{b}}$ & $31.07^{\mathrm{a}}$ & $0.28^{*}$ & 1.36 \\
\hline Shape Index, \% & 77.80 & 76.80 & 77.26 & 76.98 & 77.53 & 75.99 & 0.27 & 2.32 \\
\hline Egg surface area, $\mathrm{mm}$ & 22.38 & 21.93 & 23.02 & 22.16 & 21.40 & 22.62 & 0.24 & 2.41 \\
\hline Shell thickness, $\mathrm{mm}$ & $0.29^{d}$ & $0.30^{c}$ & $0.29^{d}$ & $0.35^{\mathrm{a}}$ & $0.31^{\mathrm{b}}$ & $0.29^{d}$ & $0.03^{*}$ & 0.01 \\
\hline$\%$ Crack & 0.87 & 0.85 & 0.87 & 0.84 & 0.81 & 0.79 & 0.01 & 0.18 \\
\hline Total egg laid & $1288^{c}$ & $1453^{b}$ & $1584^{\mathrm{ab}}$ & $1626^{a}$ & $1738^{a}$ & $1557^{b}$ & $0.79^{*}$ & 221.00 \\
\hline $\begin{array}{l}\text { Hen day production, } \% \\
\text { Internal qualities: }\end{array}$ & $61.33^{\mathrm{e}}$ & $69.19^{d}$ & $75.43^{\mathrm{bc}}$ & $77.43^{b}$ & $82.76^{a}$ & $74.14^{\mathrm{C}}$ & $1.19^{*}$ & 2.45 \\
\hline Albumen weight, \% & 47.79 & 51.95 & 52.08 & 52.04 & 52.05 & 51.99 & 0.22 & 4.55 \\
\hline Yolk weight, \% & $30.65^{\mathrm{e}}$ & $31.03^{\mathrm{d}}$ & $31.71^{\mathrm{C}}$ & $32.77^{\mathrm{a}}$ & $32.79^{\mathrm{a}}$ & $32.73^{\mathrm{ab}}$ & $0.01^{*}$ & 0.03 \\
\hline Shell weight, \% & $21.56^{a}$ & $17.02^{\mathrm{b}}$ & $16.21^{\mathrm{c}}$ & $15.19^{d}$ & $15.16^{d}$ & $15.28^{d}$ & $0.04^{*}$ & 0.12 \\
\hline Yolk diameter, $\mathrm{mm}$ & 22.06 & 20.98 & 23.51 & 21.04 & 22.43 & 22.63 & 0.15 & 2.56 \\
\hline Yolk height, mm & 8.96 & 10.04 & 9.38 & 9.25 & 9.35 & 8.82 & 0.13 & 1.38 \\
\hline Yolk index, \% & 41.00 & 48.00 & 40.00 & 44.00 & 42.00 & 39.00 & 0.16 & 9.52 \\
\hline Yolk colour & $3.03^{\mathrm{e}}$ & $4.31^{\mathrm{d}}$ & $4.75^{\mathrm{c}}$ & $5.30^{\mathrm{b}}$ & $5.65^{\mathrm{a}}$ & $5.80^{\mathrm{a}}$ & $0.02^{*}$ & 0.18 \\
\hline \multicolumn{9}{|l|}{ Composition: } \\
\hline Dry matter, \% & 30.74 & 30.02 & 30.90 & 31.34 & 31.30 & 31.28 & 1.20 & 1.41 \\
\hline Crude protein, \%DM & 46.83 & 45.68 & 45.48 & 43.45 & 43.60 & 43.56 & 0.24 & 3.46 \\
\hline Ash, \%DM & 1.22 & 1.20 & 1.10 & 1.12 & 1.18 & 1.00 & 0.35 & 0.11 \\
\hline Crude fat, \%DM & 38.14 & 39.47 & 38.50 & 38.43 & 39.26 & 41.35 & 1.94 & 3.43 \\
\hline Nitrogen Free extract, & 13.81 & 13.65 & 14.92 & 17.40 & 16.46 & 16.09 & 1.25 & 4.45 \\
\hline
\end{tabular}

production (82.76\%) up to $7.5 \%$ EeAaL supplementation implying that EeAaL could stimulate more egg production. Lower hen day production were reported by Akinfenwa et al., 2011 (68.60 - 75.78\%), Tuleun and Dashe, 2010 (62.71 - 77.02\%), and Edache et al. 2018 $(73.09-78.11 \%)$ in quails fed dietary lysine,mucuna seed and sweet potato meal, respectively.

On internal qualities, the impact of dietary treatments was observed on the yolk and shell weights as well as .05) between treatments. Egg size (9.72 - 10.37 was largest $(\mathrm{P}<0.05)$ in quails on $2.5 \% \mathrm{EeAaL}$ and least in those fed $7.5 \%$ EeAaL diet. Egg size, width, length, shell thickness, total egg laid and hen day production were influenced $(P<0.05)$ by dietary treatments. There were no effects $(P>0.05)$ of dietary treatments on egg shape index, surface area and \% crack. Shell thickness was significantly $(P<0.05)$ higher in quails fed $5 \%$ EeAaL followed by those on $7.5 \%, 0.02 \mathrm{~g} / \mathrm{kg}$ oxytetracycline and least in those fed control, $2.5 \%$ as well as $10 \%$ EeAaL diets. \% cracked eggs reduced $(P>0.05)$ at increasing level of EeAaL supplementation. Compared to the control, hen day production was higher $(P<0.05)$ in quails fed diets supplemented with either synthetic or plant extract. There was increasing trend in hen day

yolk colour. Shell weight was lower $(P<0.05)$ in quails fed EeAaL and oxytetracycline compared to those on the control diet, whereas yolk weight was significantly higher in EeAaL fed quails than in the control. This result indicated that EeAaL supplementation exerted significant influence on yolk weight. There was a rising trend in yolk colour as level of supplementation increases. The present results are consistent with previous observations reported ( Agiang et al., 2011; Akintunde et al., 2017; Edache et al., 2018; Malik et al., 2018) on quail egg quality following various supplementations. Quail egg composition did not differ 
$(P>0.05)$ between dietary treatments, indicating that EeAaL supplementation had no adverse effects on egg composition in line with previous reports (Oko et al., 2013).

\section{CONCLUSION}

The inclusion of varying levels of ethanolic extract of Aspilia africana leaf (EeAaL) on quail diets exerted significant effects on the carcass and egg quality traits of Japanese quails. Though, quails could tolerate $10 \%$ EeAaL in their diets, improved egg characteristics were obtained at $7.5 \%$ supplementation. This study therefore recommends that up to $7.5 \%$ EeAaL shoud be supplemented into quail diets.

\section{REFERENECES}

Abang, F. B., Oko, O. K. and Yelwa, J. T., 2017. Carcass and Organ Characteristics of Growing Japanese Quails (Coturnix coturnix japonica) Fed Sun-dried Mango (Mangifera spp.) Kernel Meal as a Replacement for Maize. Annual Research \& Review in Biology, 20(6):1-7.

Agiang, E. A., Oko, O. O. K. and Essien, G. E., 2011. Quails response to aqueous extract of Bush marigold (Aspilia africana) leaf. American Journal of Animal and Veterinary Sciences, 6(3): 130 -134. www.thescipub.com /pdf/10.3844/ ajavsp.2011.130.134pdf.

Akinfenwa, F. A., Bawa, G. S. and Sekoni, A A., 2011. Laying performance of Japanese quails fed varying levels of dietary lysine. In: A. A. Adeniji, E. A. Olatunji\& E. S. Gana (eds). NSAP Book of Proceedings, 36: $380-383$.

Akintunde, A. R., Omage, J. J., Bawa, G. S., Oguntoye, M. O. and Atanda, A. O., 2017.Effect of diet containing raw and processed pigeon pea seed meal on external and internal egg quality characteristics of laying quails (Coturnix coturnix japonica).Nigerian Journal of Animal Production, 44 (5): $70-77$.

Alicicek, A., Bozkurt, M. and Cabuk, M., 2004. The effect of an essential oil combination derived from selected herbs growing wild in Turkey on broiler performances. South African Journal of Animal Science, 33: 89 - 94.

Denli, M., Okan, F. and Uluocak, A. N., 2004. Effects of dietary supplementation of herb essential oils on the growth peformance, carcass and intestinal characteristicsof quail. South African Journal of Animal Science,34(3): 174-179.

Edache, J. A., Tuleun, C. D., Muduudtai, R. U. and Yisa, A. G., 2017. Laying performance and digestibility of nutrients by Japanese quails fed diets containing peeled and cooked sweet potato meal. Nigerian Journal of Animal Production, 44(3): $282-293$.
Edache, J. A., Tuleun, C. D., Oluremi, O. I. A. and Carew, S. N., 2018. Egg laying performance and economics of production of Japanese quails fed containing peeled and cooked sweet potato meal. Nigerian Journal of Animal Production, 45 (1): $141-149$.

Egbeyale, L. T., Fatoki, H. O. and Adeyemi, O. A., 2013. Effect of egg weight and oviposition time on hatchability and post hatch performance of Japanese quail (Coturnix coturnix japonica). . Nigerian Journal of Animal Production, 40: 102 -110 .

Etim, N. N., Herbert, U. And Oguike, M. A., 2017. Effect of administration of aqueous leaf extract of Aspilia africana on haematological parameters of West African dwarf sheep (Rams). International Journal of Agriculture, Forestry and Fisheries, 5(4): 39-46.

FAO, 2012.Conducting national feed assessments, by Micheal B. Coughenour and Harinder P. S. Makkar. FAO Animal Production and Health Manual No. 15, Rome, Italy.

FASS (2010).Guide for the Care and Use of Agricultural Animals in Research and Teaching. $3^{\text {rd }}$ Edition.Federation of Animal Science Societies.Pp 177.

GENSTAT (2011). GenStat Release 8.1 software package. Lawes Agricultural Trust.

Google Earth (2016). Calabar Google Earth 3D map.www.maplandia.com/nigeria/crossriver/calabar/calabar/"title" = " google satellite map accessed April 03, 2018 8.42hr).

Lee, I.M., Cook, N.R., Gaziano, J.M., Gordon, D., Ridker, P.M., Manson, J.E., Hennekens, C. H. And Buring, J.E., 2005. Vitamin $E$ in the primary prevention of cardiovascular disease and cancer: the Women's Health Study: a randomized controlled trial. Journal of American Medical Association, 294, 56-65

Malik, A. A., ljaiya, A. T., Aremu, A. and Akinwale, M. O., 2018. Growth response, carcass characteristics and egg laying performance of Japanese quail (Coturnix coturnix japonica) fed diets containing varying levels of fermented cassava (Manihot esculenta) peel meal. Nigerian Journal of Animal Production, 45 (2). $224-231$.

Mondry, R., 2016. Quail farming in tropical regions. The Pro - Agro Collection by Engineers without borders, Cameroon (ISF Cameroon) and the Technical Centre for Agricultural and Rural Cooperation (CTA), www.cta.int.31Pp.

Odetola, O. M., Adejinmi, O. O., Akingbade, A. O. and Adekanmbi, A. O., 2017. Performance and egg quality parameters of Japanese quail (Coturnix coturnix japonica) fed kenaf (Hibiscus 
cannabinus I.) seed meal based diets subjected to varying cooking periods. Nigerian Journal of Animal Production, 44(4): $225-231$.

Oko.O. O. K., Agiang, E. A. and Ozung, P. O., 2013. Hen performance as influenced by dietary Aspilia africana leaf. TH324. 2013 ADSA-ASAS JAM Annual Meeting, July 08 - 12, Indianapolis, Indiana, USA. (USA).

Oko, O. O. K., Agiang, E. A. and Eneji, C. A., 2012. Alterations in lipid profile of quails following dietary Aspilia Africana leaf extracts. XXIV

World Poultry Congress, August $05-09$, Bahia Convention Centre, Salvador- Bahia, Brazil. World's Poultry Science Journal Supplement 1. Expanded Abstact.RE_OP_2012pc136_1.pdf.

Oko, O. O. K., Agiang, E. A., Osim, E. E. and Asuquo, O. R., 2011. Toxicological evaluation of Aspilia africana leaf in mice. American Journal of Pharmacology and Toxicology, 6(3): $96-101$. thescipub.com/PDF/ajptsp.2011.96.101.pdf.DOI :10.3844/ajptsp.2011.96.101.
Oko, O. O. K., O. R. Asuquo, E. A. Agiang and E. E. Osim 2017. Neuroendocrine and behavioural responses of Japanese quails to dietary Aspilia africana leaf meal and extracts. Journal of Livestock Science, 8: 43-51. livestockscience.in/wp-content /uploads/quailbehav.pdf.

Oko, O. O.K. and Agiang, E. A., 2011. Phytochemical activities of Aspilia africana leaf using different extractants. Indian Journal of Animal Sciences, 81(8): $\quad 814 \quad$ - $\quad 818$. www.epubs.icar.org.in/ejournal/index/php/ijANS/ index/view/4072/3938.

Runjaic-Antic, D., Pavkov, S. and Levic, J., 2010. Herbs in a sustainable animal nutrition. Biotechnology in Animal Husbandry, 26: $203-214$.

Tuleun, C. D. and Dashe, N. A., 2010. Effects of dietary levels of toasted mucuna seed meal on the performance and egg quality parameters of laying Japanese quails (Coturnix coturnix japonica). International Journal of Poultry Science 9(12): 1092 - 1096. 